\title{
ROMANIAN
}

NEUROSURGERY

Vol. XXXIV | No. $3 \quad$ September 2020

\section{Organizing a microsurgery workshop for residents}

\author{
Marin Andrei, Lungu Adrian, \\ Dobrete Nicoleta Amalia, \\ Marin Georgiana Gabriela, \\ Dima Simona Olimpia, \\ Sîrbu Boeţi Mirela Patricia, \\ Popescu Irinel
}




\title{
Organizing a microsurgery workshop for residents
}

\author{
Marin Andrei ${ }^{1}$, Lungu Adrian ${ }^{2}$, Dobrete Nicoleta Amalia ${ }^{3}$, \\ Marin Georgiana Gabriela ${ }^{4}$, Dima Simona Olimpia ${ }^{5}$, \\ Sîrbu Boeţi Mirela Patricia ${ }^{5}$, Popescu Irinel ${ }^{5}$
}

\author{
1 Plastic Surgery Department, "Bagdasar Arseni” Emergency \\ Hospital, Bucharest, ROMANIA \\ 2 Rehabilitation Department, National Institute of Rehabilitation, \\ Physical Medicine and Balneoclimatology, Bucharest, ROMANIA \\ 3 Haematology Department, County Hospital Ploiesti, RomANIA \\ ${ }^{4}$ Cardiology Department, "C.C. Iliescu" Hospital, Bucharest, RomAnIA \\ ${ }^{5}$ General Surgery Department, Fundeni Hospital, Bucharest, \\ ROMANIA
}

\begin{abstract}
Microsurgery represents an important branch in Plastic and Reconstructive Surgery. It involves fine skills which doctors need to repair nerves, vessels and thus being able to perform replantation and transplantation of different types of tissue. After traumatic injuries, a plastic surgeon is capable of either coverage of the exposed noble tissue or can perform the replantation of the amputated limb using microsurgery.

This field can be very challenging at the beginning, but very rewarding in the end. The utility microsurgery is quite vast; however, the skills to perform such surgery require a lot of training beforehand. Before doing any replantation or other tissue transplant in humans, it would be recommended that a surgeon should have a basic microsurgical course completed and afterwards several hours of practice in front of the microscope. Last but not least, one should also test the skills acquired in vivo, in order to improve and perform the correct manoeuvres from the beginning. In order to do this, a plastic surgery trainee must therefore have a dedicated laboratory where he/she can practice this art. This place should be quiet, equipped with microscopes and microsurgery instruments and authorized to perform experiments on live animals.
\end{abstract}

\section{INTRODUCTION}

A growing interest in the field of microsurgery has led to the development of training facilities, where residents can practice microsurgery. [1] The development in technology has led to new ways of doing microsurgery, such as using a smartphone to use magnification. [2]

Although it is mainly addressed to the plastic surgery trainees, microsurgical skills are also useful in neurosurgery, ophthalmology,

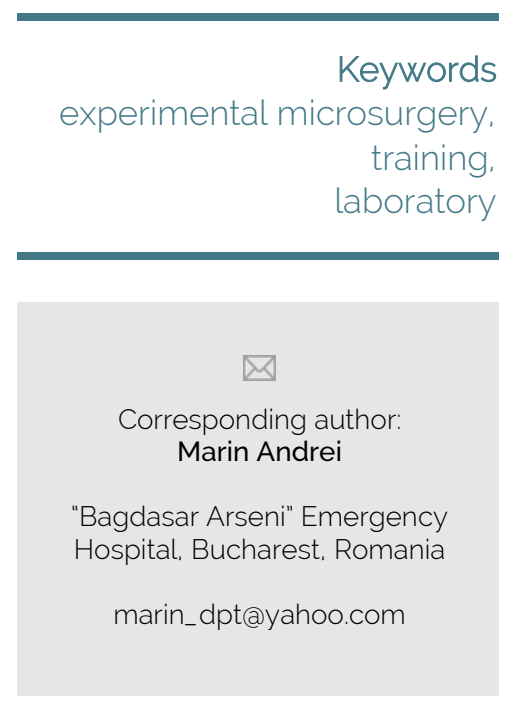

Copyright and usage. This is an Open Access article distributed under the terms of the Creative Commons Attribution Non-Commercial No Derivatives License (https://creativecommons org/licenses/by-nc-nd/4.0/) which permits noncommercial re-use, distribution, and reproduction in any medium, provided the original work is unaltered and is properly cited.

The written permission of the Romanian Society of Neurosurgery must be obtained for commercial re-use or in order to create a derivative work.

ISSN online 2344-4959 (C) Romanian Society of Neurosurgery

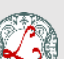

First published September 2020 by London Academic Publishing www.lapubcouk 
cardiovascular surgery, orthopedic surgery and even general surgery or urology (for liver and kidney transplant).[3],[4],[5]. A formal curriculum of microsurgery in the plastic surgery program proved to be very useful according to Mueller et. al. [6]

For this reason, there are several microsurgery centers in Romania, each having a similar basic program focused mostly on nerve and vessel repair. In time and with experience, these initial programs are developed and divided into more complex courses - involving the dissection of smaller vessels (lymphatic vessel or perforating vessel), with direct applicability in the clinical practice.

\section{MATERIALS AND METHODS}

In order to begin organizing such course, a suitable location is required. The location needs to have a veterinary employed in that facility (which is a compulsory condition for the other requirements). It would also be more comfortable for the participants if the location were far from loud noises and distraction, as microsurgery requires attention and calm.

Due to the legislation, there are several approvals needed for research or medical education involving living animals. Every project has to pass the ethics committee and afterwards get the approval from the Veterinary Department. In Romania, this process may take up to 4 months and should be planned carefully before the beginning of the course.[7] Every major project which involves a teaching activity should be performed under the supervision of the Medical University or a recognized professional association.

For the first edition of the microsurgical program, there was collaboration between 3 associations - the Romanian Multidisciplinary Residents Association, the Romanian Plastic Surgery Association and the Romanian Aesthetic Surgery Association. The course took place in 2 distinct locations - the non-living tissue experiments were performed in a private facility (MedWorkshops), while the second part which involved live animal surgery took place in CEMT -The Excellence Centre in Translational Medicine, part of the Fundeni Hospital. The course duration was 4 days ( 8 hours/day), over 2 consecutive weekends.

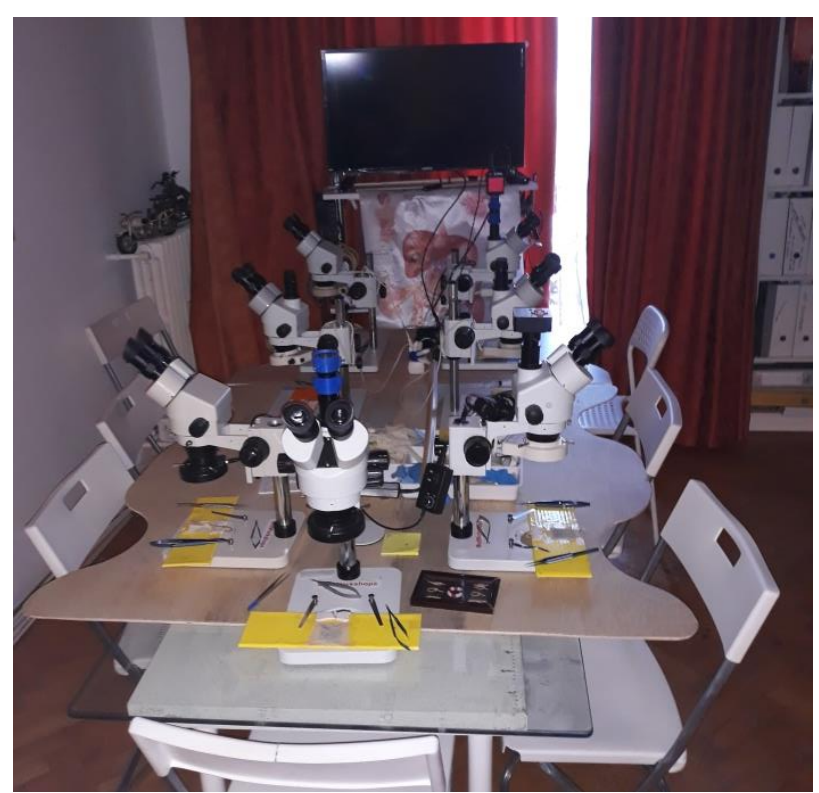

MedWorkshops Center

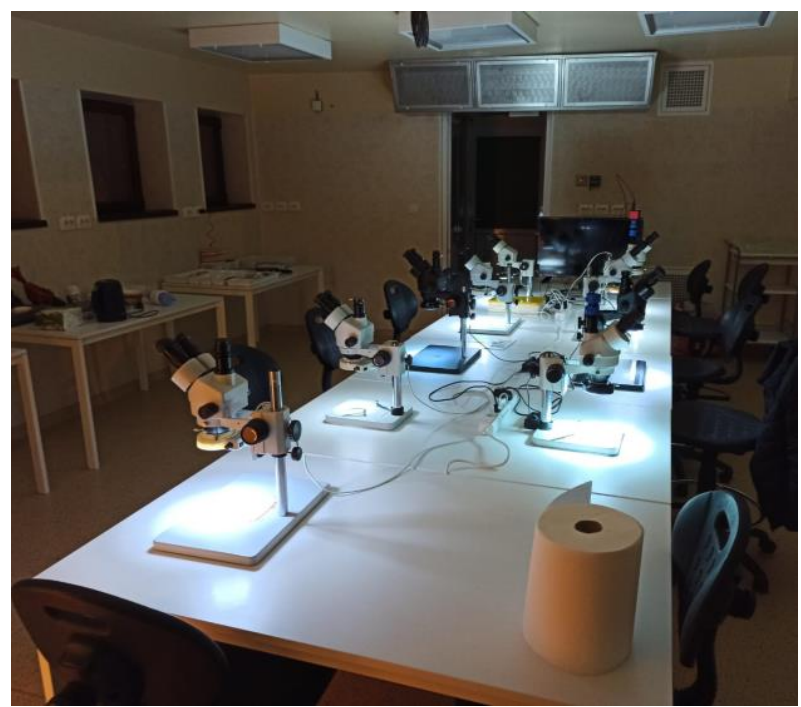

Excellence Centre in Translational Medicine

Once all the approvals were obtained, a curriculum of the course was sketched and the dates for the course established. The lecturers for the theoretical part of the course were invited with a 2 months' notice (at least) and asked for the name of their presentation. A number of 10 participants per course was considered to be suitable for a microsurgery course. The selection of the animal to be practiced on was done taking into consideration several criteria - suitable size and type of the tissue (nerves, vessels), affordable costs, easy for manipulation, easy to induce anesthesia, accessible to purchase from special laboratories. For all the previous 
mentioned reasons, the Wistar rat is the ideal candidate. [8]

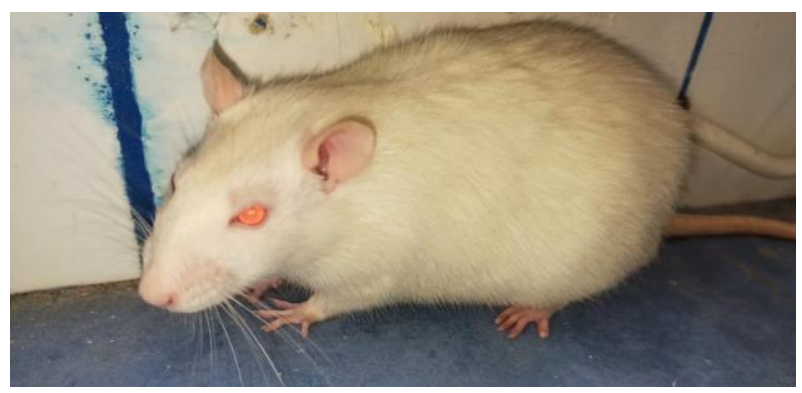

Wistar rat

The announcement of the course was done with one and a half months in advance. There were 3 channels by which the marketing was done - internet (official web sites of the associations involved, social media pages as well as personal pages), direct speech among colleagues, and posters in the hospitals which prepared residents in plastic surgery.

Poster

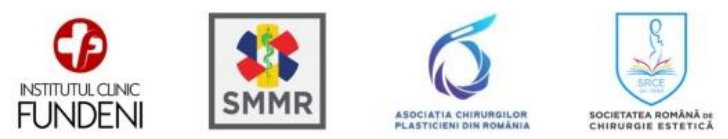

\section{Workshop: Instruire in мiсrochirurgia Experimentala \\ Editia 1 \\ Deadline inscrieri 19 ianuarie}

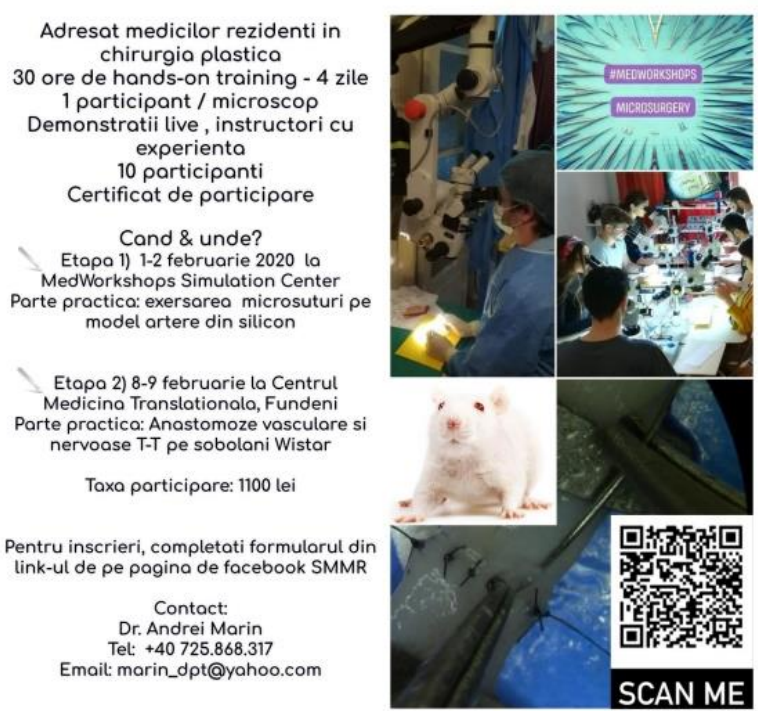

A list of all materials needed for the 4-day workshop was created. The list included instruments for the participants and trainer, other materials, logistics for the theoretical part, the material on which the participants train and food and drink supplies for catering. Based on the presumed amount of the materials used, a budget was established to support the expenses for renting of the microscopes, the facilities and acquiring all materials needed.

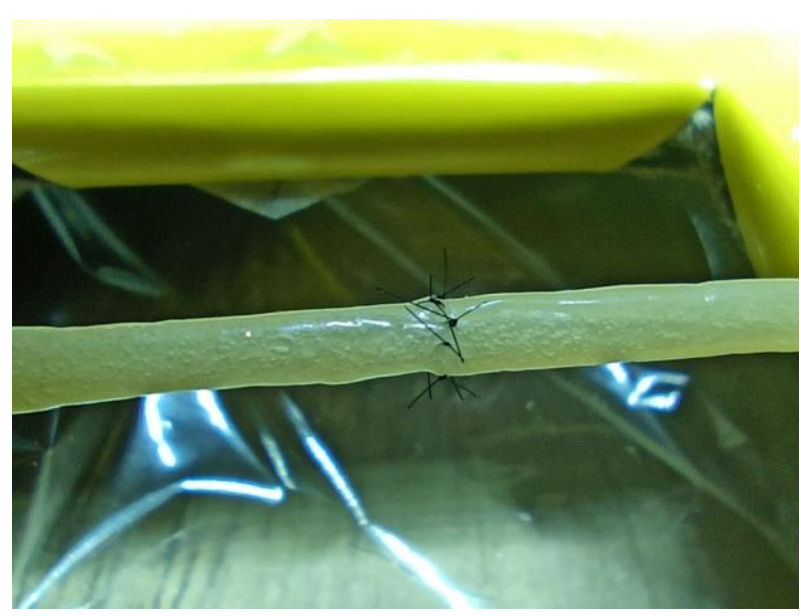

Sutured silicone tube

Table 1. List of requirements for organizing the course

\begin{tabular}{|c|c|c|c|}
\hline $\begin{array}{l}\text { Instruments \& } \\
\text { sanitary }\end{array}$ & $\begin{array}{l}\text { Other } \\
\text { materials }\end{array}$ & $\begin{array}{l}\text { Logistic } \\
\text { theory }\end{array}$ & $\begin{array}{l}\text { Practical } \\
\text { workshop }\end{array}$ \\
\hline Insulin syringes & $\begin{array}{l}\text { Black bags for } \\
\text { waste }\end{array}$ & Laptop & Latex gloves \\
\hline Syringes $10 / 20 \mathrm{ml}$ & Cages & Projector & Silicone tubes \\
\hline $\begin{array}{l}\text { Disinfectants } \\
\text { (alcohol) }\end{array}$ & $\begin{array}{l}\text { Cleaning } \\
\text { paper }\end{array}$ & $\begin{array}{l}\text { Folders \& } \\
\text { pens }\end{array}$ & $\begin{array}{l}\text { Cherry } \\
\text { tomatoes/grapes }\end{array}$ \\
\hline Gloves & First aid kit & Diplomas & Leaves and petals \\
\hline Tampons/Dressing & Cotton swabs & & Chicken legs \\
\hline Yellow cannulas & Cork plates & & Wistar rats \\
\hline Blue dye & Plastic wrap & & \\
\hline Anesthetics & $\begin{array}{l}\text { Pins and } \\
\text { paper clips }\end{array}$ & & \\
\hline Euthanasia solution & Rubber band & & \\
\hline Sutures 8.0-10.0 & Tape & & \\
\hline Sutures 3.0-5.0 & $\begin{array}{l}\text { Electronic } \\
\text { scale }\end{array}$ & & \\
\hline $\begin{array}{l}\text { Microsurgical } \\
\text { instruments } \\
\text { (scissors, needle } \\
\text { holder, forceps, } \\
\text { dilator, clamps and } \\
\text { approximator) }\end{array}$ & $\begin{array}{l}\text { Yellow bucket } \\
\text { for sharp } \\
\text { materials }\end{array}$ & & \\
\hline $\begin{array}{l}\text { Macrosurgery } \\
\text { instruments } \\
\text { (forceps, small } \\
\text { scissor) }\end{array}$ & $\begin{array}{l}\text { Yellow bags } \\
\text { for } \\
\text { contaminated } \\
\text { waste } \\
\end{array}$ & & \\
\hline Scalpel blades & Hair clipper & & \\
\hline Serum & $\begin{array}{l}\text { Background } \\
\text { material }\end{array}$ & & \\
\hline Hand sanitizers & Cups & & \\
\hline Microscopes & $\begin{array}{l}\text { Adjustable } \\
\text { chairs }\end{array}$ & & \\
\hline
\end{tabular}


Another important aspect which needed to be taken into consideration when organizing such a workshop was the fact that acquiring live animals could be done only in special conditions and from designated institutions. These institutions allow the purchase of these animals only based on the previously approved documentation.

Being an initiation microsurgery course, it needed to remain at an entry-level, both the theory and especially the practice. The selection of the participants was based on prior experience in the microsurgery training as well as year of residency. Taking into consideration the entry-level of the course, the curricula was designed to meet the experience of these participants. The program was thought to have 1,5-2 hours of theory and 6-6,5 hours of practice daily. The level of difficulty of the procedures performed was also designed to increase daily.

\begin{tabular}{|c|c|c|c|}
\hline Day 1 & Day 2 & Day 3 & Day 4 \\
\hline Theory & Theory & Theory & Theory \\
\hline Introduction in microsurgery & Vascular anastomosis & Nerve anastomosis & Clinical experience \\
\hline $\begin{array}{l}\text { Microsurgical instruments. Surgical } \\
\text { technique. }\end{array}$ & $\begin{array}{l}\text { Free flaps }- \text { clinical } \\
\text { experience }\end{array}$ & $\begin{array}{l}\text { Ethics in animal } \\
\text { experimentation }\end{array}$ & peripheral nerve repair \\
\hline Practical part & Practical part & Practical part & Practical part \\
\hline Latex glove sutures & Silicon tube sutures & Anastomosis of the & Anastomosis of the femoral \\
\hline Grape/Cherry tomato sutures & \multirow{3}{*}{$\begin{array}{l}\text { Vascular anastomosis on } \\
\text { chicken leg }\end{array}$} & femoral artery & vein \\
\hline Leaves/Petals sutures & & Sciatic rat nerve repair & Anastomosis of the aorta \\
\hline Elastic band suture & & & Anastomosis of v. cava \\
\hline
\end{tabular}

Table 2. Basic microsurgery training program

Another bureaucratic aspect of the workshop consisted of making individual folders for the participants. These folders contained the program, the list of equipment they received and for which they were responsible during the day, a file regarding work safety which they had to sign before the beginning of the course. At the end of the course the participants received a diploma and were requested to complete a feedback file.

\section{RESULTS}

After making the formal announcement of the course, 20 plastic surgery residents sent an application for one of the 10 available places. 10 participants were selected based on their microsurgical experience and the other 10 were promised a place in the next course.

The residents were in different years of training (from the 1 st to the $3 \mathrm{rd}$ ), all but one having no former experience with microsurgery (one resident having previously participated to a 2-day microsurgery course). All participants attended all 4 days of the course, except one who could not come on the 4th day.

There were 4 lecturers who presented their clinical experience in the theoretical part of the workshop and the official organizer of the course who presented and demonstrated the practical experiments.

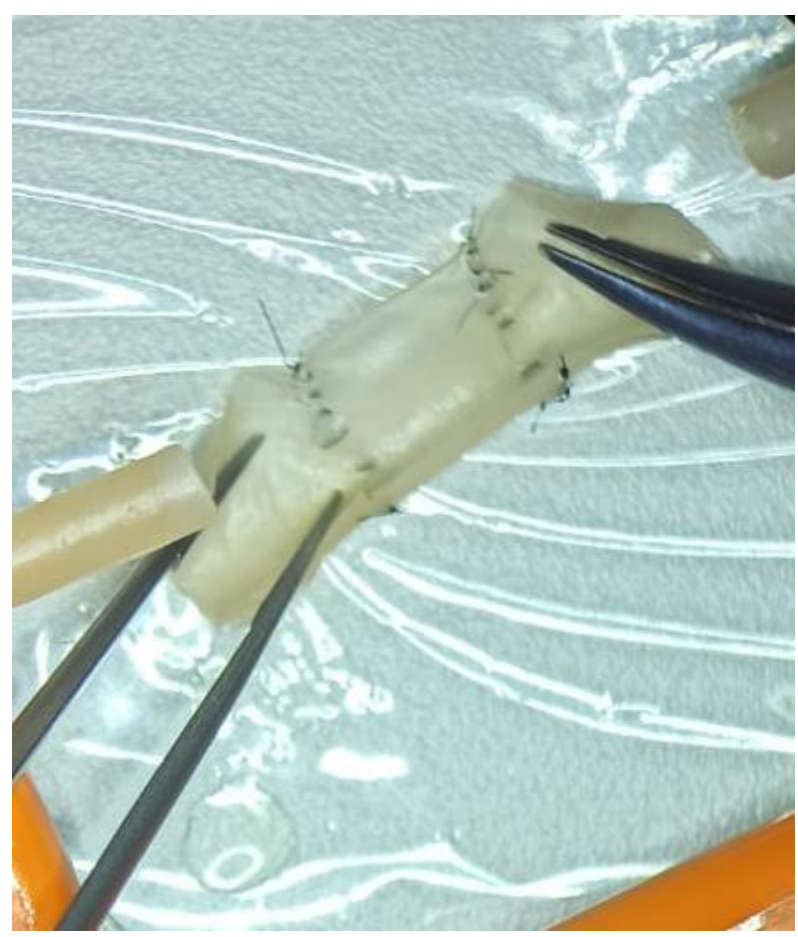

Latex tube anastomosis 


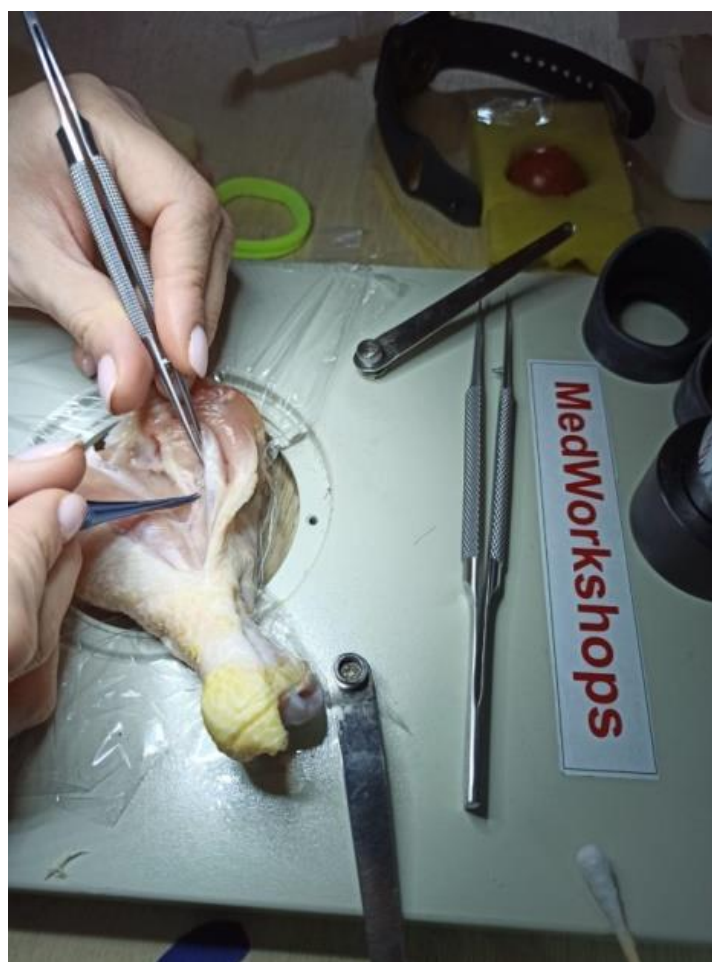

Dissection on chicken leg

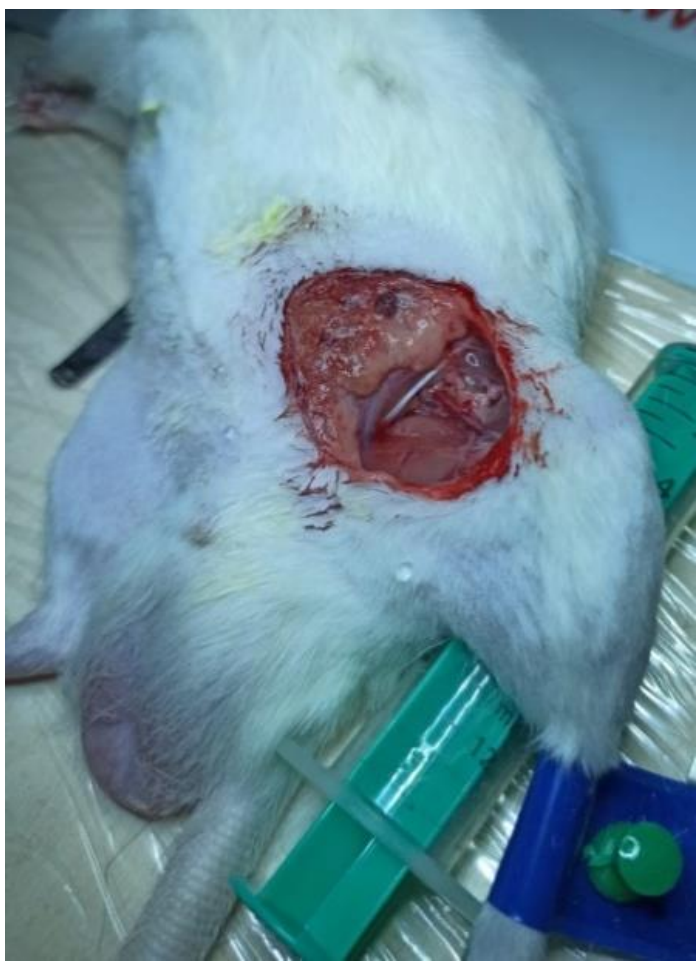

Sciatic nerve exposure

The theoretical lectures permitted the participants to learn the basics about the structure of a peripheral nerve and vessel [8],[9],[10] and also about the possibilities in the reconstruction of nerve defects, either with nerve grafts or conduits. [11],[12] Participants were also taught about the pitfalls in nerve microsurgery [13] as well as the basics in how to perform rat anaesthesia. [14]

In the practical part, the residents were also taught some tricks which they could use in order to improve their outcomes. [15]

All participants improved their microsurgical technique between the first day and the final day of the course. All participants managed to complete the tasks required in different time-frames. [16] 8/10 participants managed to achieve a patent vascular anastomosis but all participants were able to perform a correct nerve anastomosis by the end of the program.

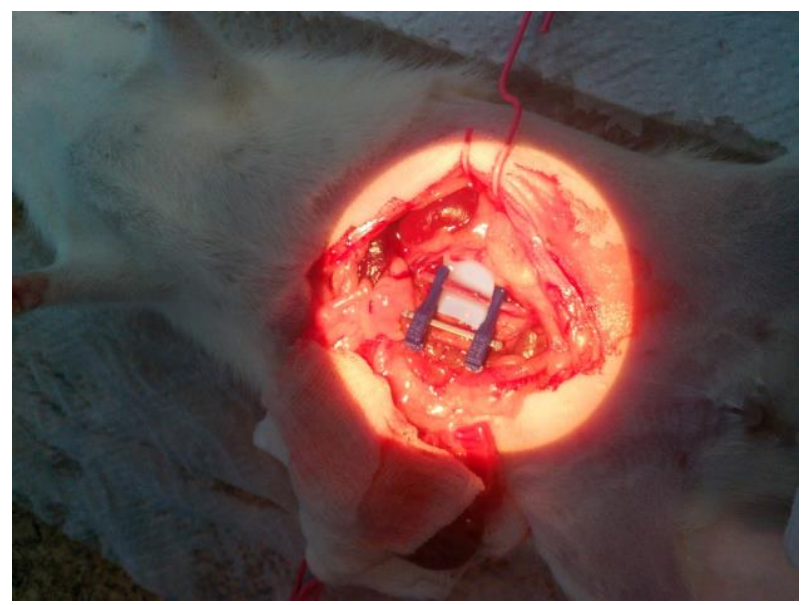

Dissection for rat aorta

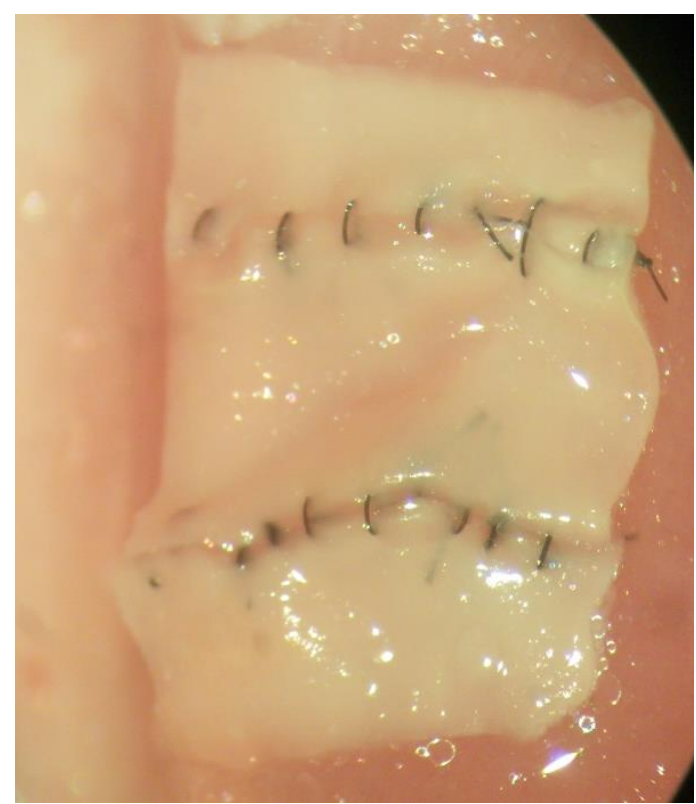

Femoral artery in chicken leg (cut open) 


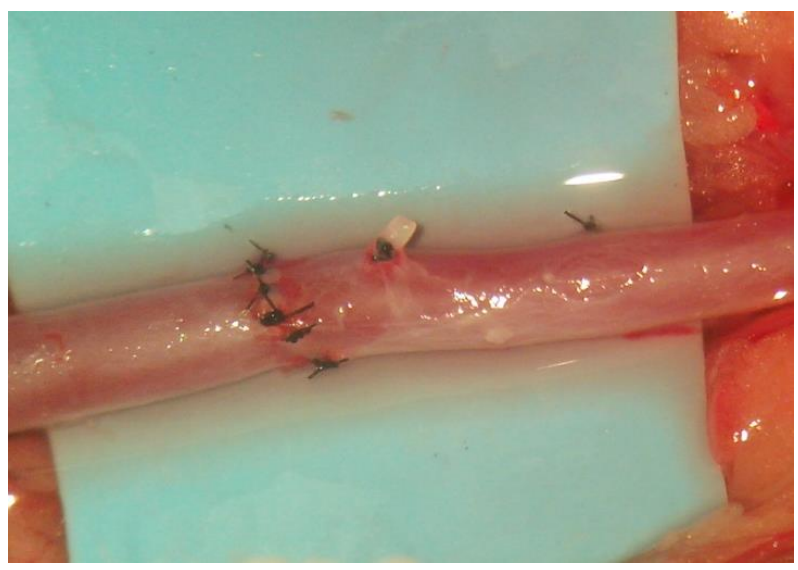

Anastomosis for femoral artery
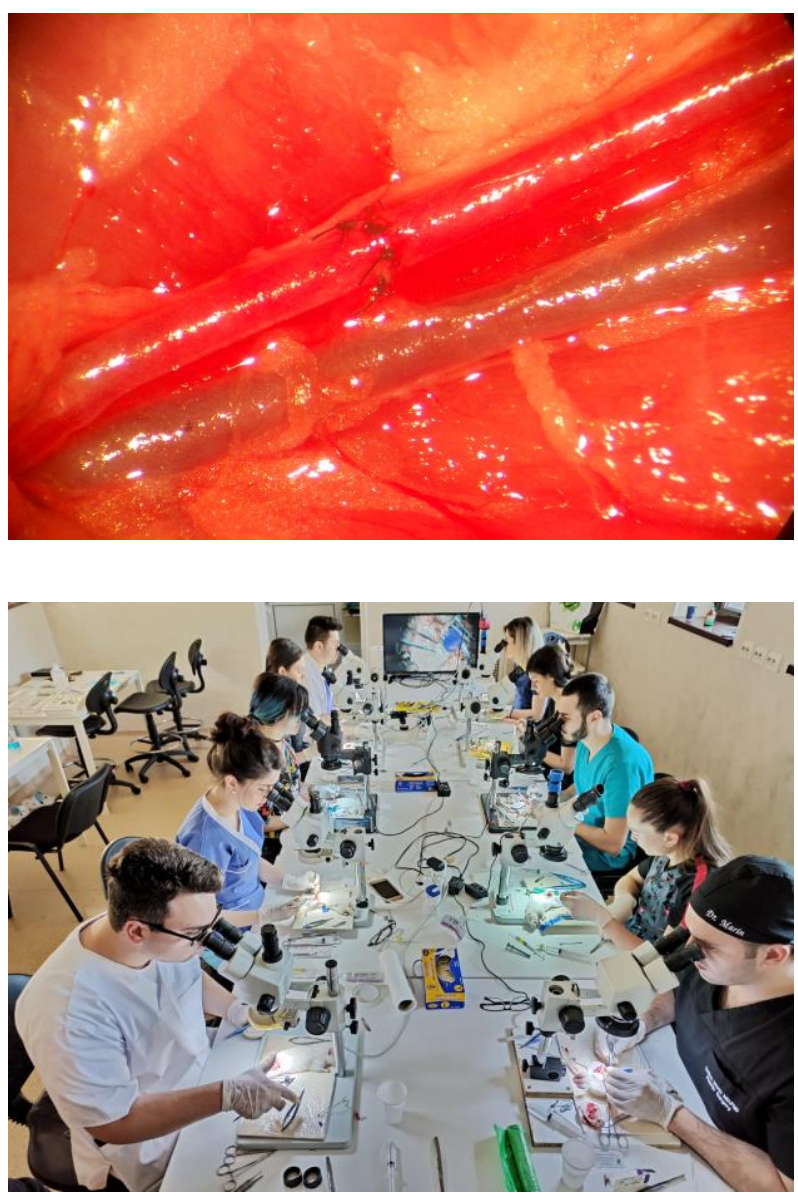

Participants during sciatic nerve repair on Wistar rat

\section{DISCUSSIONS}

Having little experience, all the participants showed great interest in microsurgery, most of them staying the full 8 hours every day (some wanting to stay even longer). However, working long hours under the microscope was strenuous (some participants complaining about minor problems: back pain or headaches associated to eyesight problems).

Since the workshop was splint over 2 consecutive weekends, the more zealous participants could also come for an extra 2 days during the week to have more practice outside the formal course. This was a great opportunity to improve their surgical skills (especially in those who had no prior experience). In the formal feedback, some participants mentioned that they would have liked an extra day of practice on live animals, so that they would be able to achieve all perfect results.

Overall, the feedback was positive and the participants said they feel more confident with their microsurgical skills, thus having no issue in performing these procedures in their clinical practice. Furthermore, they mentioned that they would gladly attend a more advanced workshop if this was to be planned.

Although this was an entry-level course, more elaborated course could be developed in time, depending on the interest of the participants.

\section{CONCLUSIONS}

Both theoretical and practical knowledge is needed when it comes to learning microsurgery skills. These should first be learned in the safe environment of a laboratory, during a microsurgery course and then applied in clinical practice.

Organizing a microsurgery course requires special equipment, designated facilities and many approvals, but such courses are absolutely needed for the training of the medical residents.

\section{REFERENCES}

1. Oltean M, Sassu P, Hellström M, et al. The microsurgical training programme in Gothenburg, Sweden: early experiences. J Plast Surg Hand Surg. 2017;51(3):193-198. doi:10.1080/2000656X.2016.1213735.

2. Capkin S, Cavit A, Kaleli T. Microsurgery training with smartphone. Mikrochirurgische Übungen mit Smartphone als Vergrößerungshilfe. Handchir Mikrochir Plast Chir. 2018;50(6):443-445. doi:10.1055/a-0661-6015.

3. Kobayashi E. New trends in translational microsurgery. Acta Cir Bras. 2018;33(9):862-867. doi:10.1590/s0102865020180090000015.

4. Pastuszak AW, Wenker EP, Lipshultz LI. The history of microsurgery in urology. Urology. 2015;85(5):971-975. doi:10.1016/j.urology.2014.12.059.

5. Hinds RM, Klifto CS, Guss MS, Capo JT. Microsurgery Case Volume During Orthopedic Surgery Residency: A 7-Year 
Assessment. Hand (N Y). 2017;12(6):610-613. doi:10.1177/1558944716675128.

6. Mueller MA, Pourtaheri N, Evans GRD. Microsurgery Training Resource Variation among US Integrated Plastic Surgery Residency Programs. J Reconstr Microsurg. 2019;35(3):176-181. doi:10.1055/s-0038-1668160.

7. Andrei Marin, Georgiana Gabriela Marin, Anca Patea, Dan Mircea Enescu. Timing, Logistics and Bureaucratic Process in Planning an Experimental In Vivo Nerve Regeneration Project from A to Z. Modern Medicine | 2019, Vol. 26, No. 2.

8. Caillaud M, Richard L, Vallat JM, Desmoulière A, Billet F. Peripheral nerve regeneration and intraneural revascularization. Neural Regen Res. 2019;14(1):24-33.

9. Lastofka, D., Manolescu, N., Balint, E., Costea, R., \& Ionescu, M. M. (2017). Histopathological modifi cations in sciatic nerve allograph in Wistar rats. Journal of Biotechnology, 256, S86.

10. Andrei, M., Ioana, M., \& Mircea, E. (2019). Underlying histopathology of peripheral nerve injury and the classical nerve repair techniques. Romanian Neurosurgery, 33(1), 17-22. https://doi. org/10.33962/roneuro-2019-003.
11. Ionescu, M. M., Costea, R., Balint, E., \& Lastofka, D. (2017). Surgery technique models of sciatic nerve allograph in Wistar rats. Abstracts/Journal of Biotechnology 256S, 44, S116.

12. Mihai Mehedintu-Ionescu, Ovidiu Stefanescu, Radu Cristian Jecan. Nervous Regeneration Allograph Type of Periferic Nerv. Modern Medicine | 2019, Vol. 26, No. 2.

13. Marin Andrei, Mihai Ruxandra Ioana, Marin Georgiana Gabriela. Pitfalls and problems encountered in rat model sciatic nerve surgery. Romanian Neurosurgery (2019) XXXIII (4): pp. 396399DOI: 10.33962/roneuro-2019-064.

14. Costea Ruxandra, Daniel Lastofka, and Mihai Mehedinţu. "Comparison of Ketamine-Medetomidine-butorphanol and Ketamine - dexmedetomidine - butorphanol Anesthesia in Rats." Agriculture and Agricultural Science Procedia 6 (2015): 305-308.

15. Marin Andrei, Mihai Ruxandra Ioana, Marin Georgiana Gabriela. Tips and Tricks in Experimental Nerve Defect Surgery. Modern Medicine | 2020, Vol. 27, No. 1.

16. Andrei, M., Gabriela, M., Amalia, D., \& Mircea, E. (2019). Learning curve in rat dissection for experimental sciatic nerve repair. Romanian Neurosurgery, 33(3), 243-248. https://doi. org/10.33962/roneuro-2019-041. 